\title{
RSP Revisitada As carreiras profissionais no serviço público
}

\author{
Ernani da Mota Rezende \\ Engenheiro da Estrada de Ferro Central do Brasil (E.F.C.B.) \\ (Trabalho classificado em 1 lugar na secção "Regulamentação \\ das carreiras profissionais", do concurso de monografias de 1940).
}

Texto publicado na RSP, vol.1, n.1, de 1941.

\begin{abstract}
Para este número especial da RSP sobre o tema Burocracia e políticas públicas, revisitamos o trabalho de Ernani da Mota Rezende, vencedor do concurso de monografias de 1940, na categoria "Regulamentação das carreiras profissionais". O trabalho discute as carreiras do serviço público quanto à remuneração e à possibilidade de ascensão funcional. Segundo o autor, o sistema de remuneração era uma forma de resolver um problema básico das relações entre empregador (no caso, o governo) e empregado: o da adequada remuneração dos serviços prestados. Ao analisar esse sistema, Ernani detectou algumas falhas e propôs alternativas, as quais acreditava serem mais justas e equitativas que o sistema em vigor na época, além de mais capazes de estimular os empregados, tanto pelo fato de melhor remunerá-los quando em desempenho de funções mais elevadas quanto por antecipar a promoção dos que mais trabalhavam. Interessante notar que o trabalho toca em temas até hoje discutidos na área de gestão de pessoas, tais como as diferenças salariais entre as carreiras e entre os setores público e privado, as nomeações, os critérios para a promoção, entre outros assuntos.
\end{abstract}

\section{I - Introdução}

1) Neste estudo consideremos a estrutura das carreiras existentes no Serviço Público Federal, em geral, e, particularmente, das carreiras profissionais de titulados.

Uma carreira é constituída por uma série de classes da inicial à final. Cada classe é caracterizada por um padrão de vencimentos e pela possibilidade de 
exercerem os seus ocupantes certas e determinadas funções. Ha funções que podem ser exercidas por empregados de classes diversas.

O ingresso na classe inicial é por nomeação, depois da prestação de concurso, na quasi totalidade das carreiras.

A mudança de uma classe para a imediatamente superior, dentro da mesma carreira e em carater permanente, é feita por promoção; esta obedece a dois critérios, o de antiguidade e o de merecimento.

Ao lado do sistema acima indicado, existem outras modalidades de empregos pagos pelos cofres do Estado, entre estas figurando:

- os cargos isolados (que pertencem ao tipo de carreira cujo número de classes se reduz a um);

- as funções gratificadas, exercidas por ocupantes de cargos de carreira ou de cargos isolados que, além do vencimento correspondente ao cargo, recebem um acréscimo de salário, que é a remuneração ou gratificação de função;

- os cargos em comissão, exercidos por ocupantes ou não ocupantes de cargos de carreira ou isolados, isto é, por empregados permanentes ou não.

Neste estudo, não levamos em consideração os empregados do Govêrno agrupados nos tipos de mensalistas, diaristas, tarefeiros, contratados ou ocupantes de cargos em comissão ou isolados; o estudo refere-se principalmente às carreiras profissionais de titulados. Conforme veremos, várias conclusões podem ser aplicadas a mensalistas e mesmo a outros tipos de empregados do Estado.

2) O sistema a que obedecem os empregados públicos civis representa uma forma de solucionar o problema fundamental das relações entre o empregador que no caso é o Govêrno - e os empregados; êsse problema básico é o da adequada remuneração dos serviços prestados.

Para o estudo que temos em vista, torna-se conveniente um rápido exame da questão dos salários em geral; tal exame é apresentado na parte II desta monografia. Segue-se um resumo histórico das carreiras profissionais no serviço público brasileiro (parte III). É examinada em seguida a situação atual do funcionalismo público (parte IV).

Tão importante quanto a remuneração de cada cargo é, para a vida do funcionário, a sua possibilidade de acesso na carreira a que pertence; o estudo desta possibilidade, em face da estatística e do cálculo de probabilidade, é feito na parte $\mathrm{V}$.

As conclusões finais são apresentadas na parte VI. 


\section{II - Salários}

3) Na sua acepção mais geral, o salário representa qualquer forma de receita que um indivíduo possa receber em troca do seu tempo ou das suas energias.

Em sentido restrito, o salário, segundo Francis A. Walker, é "a recompensa daqueles que são empregados na produção, com objetivo de lucro para os seus empregadores, e que são pagos por quotas estipuladas."

A definição de Walker é certamente inadequada para o serviço público. Em geral, os serviços de "produção" pertencentes ao Govêrno são de importância reduzida em relação ao total. No caso brasileiro atual, a maior parte dos "serviços industriais" do Estado abrange organizações de comunicações: transportes ferroviários e marítimos, correspondência postal e telegráfica.

A afirmação, frequentemente encontrada, de que "o salário é o preço do trabalho" e que, do mesmo modo que os preços das mercadorias, o salário é determinado pelas condições da oferta e da procura, está hoje geralmente abandonada, e é por certo inaplicavel à remuneração dos servidores do Estado.

A teoria de que o nivel geral dos salários pode ser considerado como resultante da ação das fôrças de oferta e de procura foi desenvolvida pelos economistas ingleses do século XIX, constituindo o que se denominou "Doutrina do Fundo de Salários". Nesta faz-se notar que na indústria os salários são na realidade pagamentos adiantados, no sentido de que são pagos antes - e algumas vezes muito antes - da entrega do produto acabado ao consumidor.

Os salários são pagos pelo capital e a procura de trabalhadores depende da parte de capital que pode ser aplicada com êste fim. O capital que é, ou que pode ser, aplicado deste modo denominou-se "fundo de salários": supondo-se que fosse pre-determinado, no sentido de que tal parte de capital dependa do que tenha sido produzido anteriormente, em quantidade e qualidade.

Os defensores desta teoria insistiam em detalhes que são verdadeiros mas que não justificam de modo cabal as conclusões a que chegavam. Um dêstes detalhes é o seguinte: a procura, em determinada ocasião, de certas mercadorias pelos consumidores, não representa procura de mão de obra e sim procura de produtos de um trabalho já efetuado.

A crítica principal à doutrina do fundo de salários baseia-se na consideração de que os salários não são pagos por um fundo fixo, mas são retirados de uma corrente permanente de riquezas. As alterações no volume total desta corrente, isto é, na produção total da indústria, têm maior influência sôbre o valor que o operário recebe do que as variações da procura relativa de mão de obra ou de mercadorias manufaturadas. Além disto, o mecanismo atual de crédito permite 
descontar do valor futuro da mercadoria acabada a parcela relativa à mão de obra, parcela que é imediatamente entregue aos trabalhadores.

Um aumento súbito na quantia total, em dinheiro, paga aos trabalhadores, como se observa algumas vezes após um período de depressão industrial, pode ter como consequência o aumento das compras de produtos manufaturados por parte dos próprios operários; si tal aumento de procura é demasiado rápido, provocará uma elevação de preços, e o aumento do poder aquisitivo dos operários não será proporcional ao aumento dos seus salários, em dinheiro.

\section{4) Os salários e o padrão de vida}

Juntamente com a teoria que acabamos de mencionar, é, em geral, encontrada a proposição de que os salários devem ajustar-se ao nível necessário para manter a população operária em seu padrão de vida habitual. Tal proposição é uma modificação de outra, anterior, segundo a qual os salários deveriam manter-se dentro dos limites mínimos necessários para a subsistência da classe trabalhadora.

Essa asserção relativa à relação entre o salário e o padrão de vida habitual baseiava-se na teoria maltusiana do aumento das populações, segundo a qual a população operária cresceria tão rapidamente quanto o permitissem os seus meios de subsistência. A teoria referida admitia tambem que o nivel dos salários deve variar inversamente à oferta de mão de obra.

Admitidas essas premissas - a lei maltusiana das populações e a variação do salário na razão inversa da abundância ou raridade da mão de obra -, a proposição relativa à interdependência dos salários e do padrão de vida seguia-se logicamente.

Uma de suas consequências, pessimista certamente, é a de que é impossível uma melhoria permanente das condições econômicas das classes operárias, exceto quando houver restrição voluntária do aumento dos seus componentes.

Para desacreditar essa teoria, é bastante observar que no último século houve uma elevação consideravel no nivel dos salários reais - isto é, do poder aquisitivo - e uma correspondente elevação do padrão de vida dos operários.

Tratando-se de serviços do Estado, nem a "doutrina do fundo de salários", nem a conservação dos salários dentro de limites estritamente necessários para manutenção do padrão de vida merecem grande consideração.

A remuneração do funcionário público - empregado necessariamente estavel - não depende de oscilações de oferta e de procura de mão de obra; sendo dever dos Govêrnos elevar o padrão de vida de todos os cidadãos, é claro que thes compete tambem a melhoria das condições dos seus empregados. 


\section{5) Os salários e o produto do trabalho}

Os modernos estudos de economia emprestam especial importância à estreita relação que deve existir entre o salário recebido e o trabalho produzido. Consequentemente, grande atenção é dada aos fatores que influem na quantidade e no valor do produto, resultado do trabalho.

À primeira vista pode parecer impossível separar a parte do produto (ou do seu valor) relativa à mão de obra, da parte correspondente ao capital, à administração, etc. $O$ produto depende inteiramente do trabalho si consideramos que não haveria produto algum si não se realizasse trabalho; porém depende tambem do uso da terra e dos recursos naturais e muito tambem do uso do capital.

A parte de um produto acabado que pode ser atribuída a um operário isolado depende da energia e da habilidade dêste operário, porém depende muito tambem das ferramentas e das facilidades que estão à sua disposição; depende ainda da riqueza dos recursos naturais à qual o operário tem acesso e da eficiência com que a indústria está organizada e é dirigida.

Mantendo-se constante a mão de obra, isto é, o número e a qualidade dos operários, e aumentando o capital produtivo, deve aumentar a produção por operário; esta aumentará tambem si forem usadas matérias primas de qualidade mais adequada, ou si forem efetuados aperfeiçoamentos nos processos técnicos de fabricação ou na organização geral da indústria.

Por outro lado, si todas as condições da indústria permanecem constantes e a mão de obra é aumentada, o aumento da produção total não será proporcional ao aumento de mão de obra: a parte atribuível a cada operário irá diminuir.

Assim, si em uma indústria existem operários todos com a mesma eficiência, a parte que toca a cada um dêles não é igual ao quociente da produção total pelo número de operários, pois com tal processo de cálculo seriam desprezados os fatores relativos ao capital, à direção, à eficiência da indústria, etc.

A parte que realmente corresponde a cada operário é muito menor que o quociente acima indicado. A cada operário deve ser atribuído um incremento do produto que está sendo fabricado, e o salário deve variar com êste incremento.

O salário deve depender da maior ou menor escassez de mão de obra somente quando esta escassez é considerada relativamente às disponibilidades existentes de outros fatores da produção: capital, matérias primas, etc.

$\mathrm{Na}$ operação de serviços industriais, o Estado deve portar-se como um empregador particular; os salários dos seus empregados devem subordinar-se, portanto, aos princípios acima apresentados: o do valor da contribuição de cada empregado e o da raridade relativa da mão de obra necessária aos seus serviços. 
Ao primeiro princípio, entre nós, é dada uma certa importância na classificação das funções: êste assunto necessita ainda, no entanto, muitos estudos para ser eficazmente empregado em sua plenitude, com justiça para os bons trabalhadores e melhores resultados para o Govêrno.

O segundo princípio - da raridade relativa da mão de obra - recebe muito pouca consideração do nosso atual sistema; são muitos os casos de técnicos de várias categorias que deixam o serviço público atraídos por maiores vantagens imediatas ou futuras em serviços congêneres da indústria particular. Por vezes verifica-se o mesmo caso, havendo porém transferência do empregado de um serviço industrial do Govêrno para outro: é o caso de operários de oficinas ferroviárias que se deslocam para os arsenais militares ou navais, onde encontram melhores salários.

O Estado age em geral como si supusesse ser ilimitada a oferta de mão de obra, o que está muito longe da verdade em um País tão pobre de técnicos habilitados. Disto resultam dificuldades no preenchimento dos quadros, com consequente baixa de rendimento dos serviços.

\section{6) As diferenças de salários}

Em todos os ramos de atividade onde existem empregados remunerados, verificam-se diferenças nos seus salários.

Tais diferenças são de duas espécies: primeiramente, as que se observam com empregados do mesmo grau de eficiência servindo em ocupações diferentes, ou na mesma ocupação em localidades diversas; em segundo lugar, encontram-se as diferenças de salários devidas a diferenças de habilidade e eficiência.

Quando os salários de operários de mesma eficiência variam de uma ocupação para outra, pode-se em geral explicar tais variações pela diversidade de crescimento das várias indústrias, com a consequente maior procura de certas especializações.

As diferenças verificadas entre a remuneração de operários do mesmo ofício e da mesma eficiência, em localidades diferentes, são explicaveis pela ignorância de melhores oportunidades em outros lugares, pelas despesas necessárias à mudança, pelas ligações locais, pelas barreiras políticas. Tais diferenças não devem ser confundidas com outras, em geral muito maiores, que se verificam entre o nivel geral de salários em um país e em outro, estas últimas dependendo de variações no suprimento de matérias primas, da organização geral do trabalho, da maior ou menor industrialização dos diversos países.

Quanto à relação existente entre os salários e a maior ou menor habilidade do artífice, seja essa habilidade inata ou adquirida, não ha dúvida de que essa relação 
existe quasi que de modo absoluto. Não se verifica, no entanto, proporcionalidade entre a remuneração e a habilidade. Não existe expressão exata para essa interdependência, porém várias observações indicam que a remuneração cresce mais rapidamente do que a habilidade; partindo dos salários mais baixos, para os mais altos, a capacidade de ganho parece aumentar mais rapidamente do que a capacidade de produção dos empregados. Isto é explicavel por várias razões. Uma destas é a de que os operários não são remunerados pela sua capacidade e sim pela sua eficiência; esta última depende tanto da educação e do treinamento como da capacidade natural, e a educação e o treinamento são em parte dependentes das oportunidades.

A questão é bastante complexa; existem certas diferenças de salários que podem ser consideradas "normais", como as classificou Adam Smith, e que dependem das dificuldades e despesas que devem ser vencidas para a aprendizagem, da estabilidade maior ou menor do emprego, do grau de responsabilidade, das possibilidades de progresso e melhoria, das condições mais ou menos agradáveis do serviço.

Deve-se observar que os trabalhadores menos capazes de escolher seus empregos são frequentemente forçados a aceitar uma combinação muito desvantajosa, de modo que os empregos mais desagradaveis e de menor possibilidade de acesso são tambem os de peor remuneração.

Reconhece-se que o contrôle dos meios trabalhistas, pelas associações de classe ou pelos Govêrnos, apresenta a tendência de diminuir as diferenças de salários dos trabalhadores submetidos ao controle, quando, ao contrário, tende a aumentar as diferenças entre o nivel de salários dos trabalhadores submetidos ao contrôle e o nivel dos operários que estão fora dêsse contrôle.

Todos os fatores que desviam os homens das carreiras mais proveitosas tendem a aumentar o número dos concorrentes aos lugares inferiores tendendo a tornar tais lugares ainda menos atraentes.

A complexidade da vida moderna não permite medir separadamente a eficiência e a produtividade de cada empregado, como se poderia pensar em fazer por meio de tests das capacidades físicas e mentais.

A produção de uma indústria não se pode obter pela adição das partes relativas a cada um dos seus trabalhadores. A eficiência de um homem afeta diretamente os resultados dos esforços de vários outros; no conjunto da indústria, a função de cada empregado corresponde mais à de um fator multiplicativo do que à de uma parcela aditiva. Um bom contra-mestre, aumentando a produção dos seus subordinados, pode, não sómente melhorar os salários destes, como aumentar consideravelmente a sua própria remuneração. 
O homem mais capaz de dirigir uma grande indústria pode realmente ganhar o dôbro do que um outro cuja capacidade é apenas ligeiramente inferior à sua.

Pelos tests de eficiência, avaliando a capacidade de dois empregados isolados, pode se achar uma certa diferença entre êles: a diferença entre os salários que cada um consegue pode, no entanto, ser exageradamente superior às das capacidades assim verificadas.

Nos serviços públicos brasileiros, a diferença de salários é uma das características principais.

A grande maioria dos cargos é de carreira, constituindo êles uma série de postos de niveis de salários diferentes. Além de diferença de remuneração, cada cargo apresenta outras características, tais como a possibilidade de exercer o seu ocupante certas e determinadas funções.

Para os diversos serviços, existem carreiras especiais, com niveis diferentes de remuneração. Esta diferença corresponde à que indicamos em primeiro lugar: salários diferentes para empregados servindo em ocupações diversas ou na mesma ocupação em lugares diferentes.

Dentro de uma mesma carreira, as diferenças de remuneração entre seus diversos cargos correspondem ao segundo caso que considerámos: diferenças de salários devidas a diferenças de habilidade e eficiência.

Do modo de aumentar o salário no serviço público - o que, dentro de uma carreira, se obtem pela promoção -, trataremos em detalhe em outro capítulo.

No caso do serviço público, a ação das fôrças econômicas na fixação ou no reajustamento dos salários é consideravelmente retardada, pois a modificação desses salários só é possível mediante o funcionamento da máquina administrativa, desde o encarregado do serviço, que observa a necessidade ou conveniência de alterar a remuneração dos seus subordinados, até os altos poderes da República.

\section{7) Os Sistemas de salários}

A legislação brasileira estabelece diversos tipos de remuneração para as diversas classes de empregados do Govêrno - titulados, mensalistas, diaristas, tarefeiros, contratados, empregados de obras.

Examinamos a seguir os principais sistemas de salários em vigor nas indústrias em geral, comparando, quando conveniente, essas normas gerais com as adotadas pelo Govêrno Brasileiro.

Existem dois sistemas normais de remunerar o trabalho dos empregados nas indústrias do sistema capitalista: o pagamento de diárias e o de ordenados. 
Não é facil traçar uma linha de demarcação nítida entre essas duas formas de pagamento. As diárias são em geral pagas por semana ou por quinzena e os ordenados por períodos maiores - meses ou trimestres, por exemplo. Existem, no entanto, casos de ordenados semanais ou quinzenais e de diárias pagas por mês. É muito grande a variedade de tipos de remuneração que existe entre o "ordenado anual" e o pagamento por hora de serviço.

Em geral o pagamento de ordenados ou vencimentos caracteriza os empregados de categoria mais elevada ou de situação mais segura.

As "diárias" são, por via de regra, pagas somente pelas horas de serviço, e qualquer interrupção dêste, por moléstia ou outro motivo qualquer independente do contrôle do operário ou não, importa na interrupção dos pagamentos. Os empregados que recebem ordenados, por outro lado, são em vários casos pagos durante os períodos de doença, ou durante as ausências devidas a outras causas.

A remuneração por diárias corresponde, em geral, a menor estabilidade e a um menor prazo de avizo prévio em caso de demissão.

O período adotado como base para o cálculo das diárias varia de uma indústria para outra, de lugar para lugar e mesmo de uma fábrica para outra. Em alguns casos, a base é o pagamento por hora de serviço; em outros, é fixado o salário semanal, quinzenal ou mensal correspondente.

Encontra-se por vezes o salário semanal garantido, que é um mínimo a ser pago por semana, qualquer que seja o número de horas ou de dias de trabalho; em outros casos, existe a diária garantida, não havendo, no entanto, salário garantido por semana: êste último tipo é frequente nos serviços de estiva.

De um modo geral, as garantias dadas aos operários tendem a aumentar em todas as indústrias.

\section{8) Sistemas de diárias}

Os métodos de remunerar os empregados por meio de diárias podem classificar-se em dois grupos principais:

- o de pagamento pelas horas de serviço;

- o de pagamento pelos resultados do trabalho.

Existem naturalmente muitas variedades intermediárias.

No pagamento pelas horas de serviço, a remuneração varia com o tempo que o empregado realmente despende a serviço do empregador.

Assim, na Grã Bretanha, antes da guerra atual, o salário de carpinteiros e marceneiros, na indústria de construção, era de 1 shilling e 8 pence por hora; nas 
estradas de ferro, a maioria dos empregados recebia salários semanais de 46 shillings para cima.

Êstes pagamentos por tempo são praticamente sempre fixados em relação a um número determinado de horas por semana; e sendo necessário trabalhar maior número de horas, denominadas extraordinárias, são estas horas excedentes em geral remuneradas com uma base horária ligeiramente superior à da hora comum (cada hora extraordinária valendo uma hora e um quarto, uma hora e um terço, duas horas, etc.).

O pagamento por tempo é encontrado em grande número de indústrias, entre estas a maioria das indústrias de construções e dos serviços de transportes ferroviários e rodoviários, e a quasi totalidade dos empregos não manuais.

Frequentemente é êsse método de pagamento encontrado lado a lado com vários métodos de pagamento pelos resultados obtidos.

\section{9) Sistemas de pagamentos pelos resultados obtidos}

Nestes métodos, de que existem várias modalidades, a característica principal é a de variar a remuneração do empregado com a sua produção, seja esta produção devida exclusivamente ao seu trabalho individual ou resultante do labor do empregado considerado juntamente com o de outros companheiros seus.

O salário pode depender de outros fatores, pois tais métodos de pagamento são frequentemente associados a "diárias" ou ordenados fixos, que representam a remuneração mínima a que o empregado tem direito, qualquer que seja a sua produção.

A forma mais simples de pagamento pelos resultados é a do salário por peça; neste caso, é fixado o preço por unidade do artigo em cuja execução trabalha o empregado; assim, si êste se ocupa da fabricação de parafusos, é fixado o preço por centena ou por groza de parafusos, êste preço sendo calculado, teoricamente ao menos, de acôrdo com o tempo necessário para execução da tarefa.

Os métodos de pagamento por peça variam muito com a maior ou menor complexidade da indústria. Quando as operações da fabricação são simples e as mercadorias uniformes, os preços de pagamento por peça podem ser estabelecidos com precisão quasi matemática; quando os produtos são diversos, as complicações são inevitaveis. Assim, é mais facil estabelecer os preços das peças produzidas em oficinas altamente especializadas do que em fábricas que têm a seu cargo a produção de artigos variados.

Uma dificuldade séria na fixação dos preços por peça é encontrada na diversidade das máquinas de que dispõem os operários para o serviço, máquinas que são diferentes de uma oficina para outra e por vezes dentro da mesma oficina. 


\section{0) Método dos "Bonus ou Prêmios"}

Um outro processo de pagamento pelos resultados é o dos "bonus de produção".

Neste, o operário recebe geralmente um salário proporcional às horas de serviço, independente da produção obtida; quando, porém, esta excede um mínimo prefixado, o empregado recebe um "bonus" extra, calculado sôbre a produção suplementar. Ha uma grande variedade de modos diferentes de calcular os bonus, dos quais os mais importantes são o "Halsey" e o "Rowen".

Em ambos êstes processos fixa-se um "tempo de base" para o desempenho de determinada tarefa. Caso esta esja concluída antes do tempo de base, o operário recebe um bonus proporcional ao tempo economizado, além do salário normal que receberia si houvesse executado o serviço no tempo normal. Tanto no sistema Halsey como no Rowen, a remuneração do operário aumenta quando a produção cresce; o aumento de remuneração não é, porém, proporcional ao aumento de produção, de modo que, para o empregador, o custo do produto decresce com o aumento de produção.

No processo Halsey, o pagamento extra que o operário recebe corresponde a uma fração do tempo economizado. Assim, sendo o salário de $1 \$ 0$ por hora e 6 horas o tempo previsto para execução de determinada tarefa, o operário receberá $6 \$ 0$ si executar o serviço dentro do tempo normal; si dêle se desempenhar em 4 horas apenas, receberá $4 \$ 0$ de salário mais $1 \$ 0$ de prêmio, ou seja um total de $5 \$ 0$ por 4 horas de trabalho. Nas horas economizadas, naturalmente, o operário ficará ocupado em outra tarefa, idêntica ou não, vindo, portanto, a receber mais por dia de trabalho do que si executasse o serviço no tempo normal; no exemplo acima o operário teria direito a $8 \$ 0$ por dia de 8 horas executando seu trabalho no tempo normal, enquanto que receberá $9 \$ 0$ por dia devido à economia de tempo.

O processo Rowen, bastante mais complicado, pode ser explicado nas suas linhas gerais dizendo-se que a cada $10 \%$ de tempo economizado corresponde um aumento de salário de $10 \%$.

Deve-se notar que tanto o método de salário por peça ou tarefa como os métodos de pagamento de bônus, nas suas múltiplas variedades e combinações, podem ser aplicados a indivíduos isolados ou a grupos de empregados. Neste último caso, cada grupo constitue uma unidade, os pagamentos por peça ou tarefa ou os bonus e prêmios sendo pagos em relação à produção de todo o grupo. São os bonus ou prêmios coletivos, etc.

Ha vários casos de pagamentos de prêmios baseados sôbre a produção ou o lucro total de uma empresa, independentemente dos pagamentos relativos aos salários individuais. 
Os modos de efetuar a divisão dos bonus coletivos, isto é, atribuidos a grupos de empregados, variam muito tambem; podem, por exemplo, ser uniformes para todos os beneficiados ou proporcionais aos salários de cada um.

\section{1) Comissões}

Um outro sistema de remuneração do trabalho, diverso do de pagamento por peça ou tarefa e dos vários sistemas de bonus ou prêmios, é o de "pagamento de comissões", aplicado em certos dados.

Neste sistema o empregado recebe uma comissão sôbre os negócios efetuados ou os lucros obtidos nesses negócios, seja como sua única remuneração, seja como um adicional de um salário mínimo prefixado.

Este modo de remuneração é de uso muito mais geral no comércio do que na indústria; é usado especialmente com os agentes de companhias de seguros, caixeiros viajantes, representantes.

\section{III - Resumo histórico sôbre as carreiras profissionais no serviço público brasileiro}

12) O princípio da organização de carreiras em geral, no serviço público brasileiro, está indicado na Constituição (Art. 156, letra b) quando trata do ingresso na classe inicial.

Êsse princípio, da formação e organização das carreiras, foi introduzido na legislação brasileira pela Lei no 284, de 28 de Outubro de 1936 (art.1ํ).

Anteriormente a essa lei, os cargos públicos eram preenchidos por nomeação e não por promoção, não sendo assegurada ao funcionário, por mais zeloso, a possibilidade de acesso a postos mais elevados. Atualmente o preenchimento de cargos por promoção no caso dos cargos de carreira está regulado em detalhe; a primeira investidura só pode dar-se nos cargos iniciais.

A Lei no 284 trouxe tambem a padronização dos vencimentos, de que havia uma variedade enorme; foram estabelecidos 23 padrões, designados pelas letras A até $X$, o mais baixo (A) correspondendo a 2:400\$000 anuais e o mais elevado (X) a 90:000\$000 anuais.

O funcionário público civil foi distribuído por essa lei, dentro dos respectivos Ministérios, em quadros designados pelos números romanos: I, II, III, etc., em quantidade variavel para os vários Ministérios, incluidos nestes os da Guerra e da Marinha. 
$\mathrm{O}$ art. 70 da Lei no 284 previu a revisão dos regulamentos das repartições públicas, a fim de adaptá-los aos novos dispositivos, muito havendo ainda que fazer neste sentido.

Ainda segundo a lei referida, foi creado o Conselho Federal do Serviço Público Civil, diretamente subordinado ao Presidente da República, constituído por cinco membros de livre escolha dêste; as atribuições principais dêsse Conselho eram o estudo dos serviços públicos, a realização de concursos para o provimento dos cargos públicos e o seu funcionamento como órgão consultivo em questões de pessoal nas repartições.

Foram também creadas as Comissões de Eficiência, uma para cada Ministério, encarregadas dos estudos de organização dos serviços do Ministério respectivo e a sua racionalização, das propostas de nomeação, promoção e transferência de funcionários, etc.

A Lei no 284 determinou no seu artigo 19:

Art. 19 - Os serviços públicos civis serão executados pelos funcionários cujos cargos constam das tabelas anexas a esta lei e por pessoal extranumerário.

“Parágrafo único. O pessoal extranumerário, classificado em contratado, mensalista, diarista e tarefeiro, será admitido na forma da legislação que vigorar, de acôrdo com a natureza e necessidade dos serviços a serem executados e pelo prazo que fôr indispensavel.

Ficaram assim os empregados do Govêrno divididos em duas categorias principais, a dos funcionários e a do pessoal extranumerário. A Constituição de 10 de Novembro não se refere aos extranumerários.

A Lei no 284 eliminou (art. 21) todo e qualquer estipêndio atribuído até então aos funcionários públicos, a título de abono ou de gratificação, que não constasse de tabelas anexas à referida lei.

O regime do tempo integral foi determinado (art. 22) para os diretores dos órgãos componentes das Secretarias de Estado; pela Constituição de 10 de Novembro êste dispositivo foi estendido a todo o funcionalismo. 0 art. 29 da Lei no 284 previa o estabelecimento do tempo integral para certos cargos técnicos, científicos e de magistério, a entrar em vigor quando o decidisse o Govêrno, sendo então previsto melhor pagamento aos funcionários.

As bases para promoção de funcionários, estabelecidas no art. 33 e seguintes da Lei $n=284$ foram as seguintes: 
- metade das promoções obedeceria ao critério de antiguidade e metade ao de merecimento, exceto nas promoções para a classe final da carreira, que seriam todas por merecimento;

- nas promoções por merecimento, teriam preferência os funcionários classificados por concurso;

- as promoções por merecimento seriam feitas dentre os funcionários constantes de lista tríplice organizada previamente pela Comissão de Eficiência respectiva, só podendo ser incluidos nesta lista os funcionários colocados nos dois primeiros terços de sua classe na ordem de antiguidade, excetuado o caso de promoção à última classe da carreira;

- seria obrigatório o interstício de dois anos para promoção.

Algumas funções, tais como de secretário, chefe, oficial e auxiliar de gabinete, deveriam ser exercidas em comissão, por pessoa de livre escolha, observados os regulamentos respectivos.

Um sábio dispositivo da Lei no 284, talvez o de maior alcance para o aperfeiçoamento dos serviços públicos civis, foi o que estabeleceu os concursos para provimento dos cargos iniciais das carreiras, dispositivo êste que foi confirmado pela Constituição de 10 de Novembro.

13) Com o Decreto-Lei no 2.290, de 28 de janeiro de 1938, entrou em vigor o Regulamento de Promoções dos Funcionários Públicos Civis, o qual foi alterado em alguns pontos pelo Decreto no 3.409 de 6 de dezembro de 1938, sofrendo ainda pequenas alterações posteriormente.

Em suas linhas gerais, o regime de promoções obedece às normas seguintes:

- a promoção é ato do Presidente da República;

- as promoções obedecem ao critério alternado de antiguidade de classe e de merecimento, exceto quando à classe final da carreira, em que obedecem exclusivamente ao merecimento;

- as propostas de promoção competem privativamente às Comissões de Eficiência, cabendo aos Serviços de Pessoal das diversas repartições a apuração dos elementos necessários;

- a promoção por antiguidade recairá no funcionário mais antigo da classe, na data da vaga originária;

- a promoção por merecimento recairá no funcionário escolhido pelo Presidente da República, dentre os que figurarem na lista organizada pela respectiva Comissão de Eficiência, lista esta que será organizada para cada classe, contendo três nomes para cada vaga; 
- é indispensavel o interstício de dois anos para promoção, inclusive à classe final da carreira;

- as promoções às classes intermediárias de cada carreira poderão recair, por merecimento, somente nos funcionários colocados nos dois primeiros terços de sua classe.

14) O mecanismo adotado para as promoções é bem detalhado nesse regulamento; outros esclarecimentos, detalhes e pequenas modificações foram posteriormente adotados e postos em vigor.

A parte relativa a promoções por antiguidade é relativamente simples, muito maior sendo a complexidade da parte correspondente às promoções por merecimento.

Não ha negar a necessidade de que se ressentia o serviço público civil de regulamentação neste assunto. O sistema atual parece-nos, no entanto, complicado quando se trata de empresas de grande número de empregados que são aliás as que mais necessitam de regulamentação adequada.

As promoções por merecimento baseiam-se nos "boletins de merecimento" fornecidos pelos chefes de serviço, boletins êstes que consideram vários itens (eficiência no serviço, compreensão de responsabilidades, qualidades de cooperação, caráter, conhecimento do serviço, urbanidade no tratamento com outras pessoas da repartição ou não, capacidade de direção); tais boletins devem ser expedidos de quatro em quatro meses, sendo a sua confecção e preenchimento detalhados em várias circulares e ordens de serviço.

Não entraremos em detalhe no estudo dêsses boletins, pois no presente estudo êles só nos interessam do ponto de vista geral. Consideramos somente o mecanismo das promoções em si, e assim podemos ver que, obedecendo a emprêsa ou o serviço ao sistema de organização vertical, no qual cada chefe tem sob suas ordens um número reduzido de subordinados diretos, o trabalho dos chefes é relativamente simples, tendo êles que fornecer informações e boletins de poucos subordinados seus; necessariamente, porém, muitos serão os funcionários aos quais compete a atribuição de graus de merecimento e muito difícil será que todos possuam o mesmo critério, dada a latitude dos pontos a atribuir, que variam para os diversos itens do merecimento, em alguns casos de zero a dez, em outros de zero a vinte e em outros ainda de zero a trinta pontos. Assim parecia aconselhavel, no caso de ser mantido êsse sistema, que o mesmo fôsse simplificado, sendo reduzidas as variedades de pontos a atribuir: para cada uma das condições de merecimento poderiam ser atribuídos somente três ou quatro graus (por exemplo, mau, sofrivel, bom, ótimo), a cada grau correspondendo, conforme a condição de merecimento a que se referisse, um 
número fixo de pontos; assim, à nota "ótimo" corresponderiam dez pontos nas condições cuja avaliação é feita de zero a dez, ou vinte nas de zero a vinte, etc.; ao grau "bom" corresponderiam sete pontos, quatorze ou vinte e um conforme as condições, etc.

Quando a emprêsa ou o serviço obedece ao sistema de organização horizontal, no qual cada chefe ou encarregado tem autoridade imediata sôbre um grande número de subordinados, aumenta a dificuldade do conhecimento dos subordinados para a correta atribuição de pontos; aumenta tambem o trabalho material do chefe a quem compete a organização dos boletins, vindo êste chefe a ter que dedicar à confecção de boletins um tempo apreciavel; existem chefes de serviço - na Central do Brasil, por exemplo - que têm o encargo de organizar boletins de mais de um milheiro de funcionários; admitindo-se que trabalhe concienciosamente, o tempo de cinco minutos para cada boletim não é certamente demasiado, o que corresponde, para mil boletins, a cinco mil minutos ou sejam quasi duas semanas de trabalho ininterrupto por quadrimestre.

Assim, parece que, em ambos os casos de organização - vertical ou horizontal -, é aconselhavel uma simplificação no método atual de avaliação do merecimento.

15) O pessoal extranumerário e para obras teve a sua situação regulada pelo Decreto-Lei 240, de 4 de fevereiro de 1938.

O art. 19 da Lei no 284 previa a divisão dos empregados do Govêrno em duas categorias, a dos funcionários e a do pessoal extranumerário; a Constituição (art. 156) refere-se somente aos funcionários; o Decreto-Lei no 240 regula as questões do pessoal extranumerário e introduz mais uma categoria, que é a do pessoal para obra. A divisão do pessoal extranumerário em contratado, mensalista, diarista, tarefeiro, indicada na Lei no 284 , é mantida no Decreto-Lei no 240 , que assim diz:

Art. 1o - Além dos funcionários públicos civis, regularmente investidos em cargos públicos creados por lei, poderá haver, nos serviços públicos federais, pessoal extranumerário.

Art. 2ㅇ- O pessoal extranumerário será sempre admitido, ou reconduzido, a título precário, com funções determinadas e salário fixado, dentro dos limites das dotações orçamentárias próprias da verba pessoal, parte variavel.

Art. 3o- 0 pessoal extranumerário se divide em:

I- Contratado.

II - Mensalista.

III - Diarista.

IV - Tarefeiro. 
No presente estudo merecem consideração os mensalistas e os diaristas, pois que a êstes podem ser aplicados alguns dos princípios da organização de carreiras, embora tais carreiras não sejam tão definidas como as dos funcionários públicos.

Pelo art. 5o do Decreto-Lei no 240, a admissão, recondução ou melhoria de salário dos mensalistas depende de autorização do Presidente da República.

Para os mensalistas, o princípio de organização de carreiras consta do art. 23 do Decreto-Lei no 240:

Art. 23 - Quando houver vaga em função que não seja a de menor salário na tabela respectiva, a admissão se fará por aproveitamento do mensalista de salário imediatamente inferior, desde que prove a necessária habilitação...

\section{IV - O serviço público brasileiro}

16) Conforme vimos nos capítulos relativos aos "Salários", o problema que êstes apresentam é complexo e admite várias soluções. $O$ tipo ideal em cada caso seria o que permitisse maiores vantagens para o empregador e para o empregado - o que é difícil de conseguir, pois os interesses respectivos são muitas vezes opostos.

No caso de empregos públicos, esta questão, considerada em conjunto, é talvez mais difícil ainda, dada a variedade de funções dos empregados do Govêrno, as quais vão desde as tipicamente burocráticas até as de carater acentuadamente industrial; acrescentando a esta diversidade de funções a necessidade de uniformizar a legislação para todo o pessoal, vê-se a grande dificuldade que existe para atender do modo melhor a cada caso particular, do serviço ou do empregado.

A situação do empregado público brasileiro, cuja legislação examinámos rapidamente no "Resumo histórico", relativamente ao assunto principal desta monografia, que é constituído pelas carreiras profissionais, é definida atualmente por duas leis principais: o Estatuto dos Funcionários Públicos Civis e a Lei de Promoções. O resumo histórico anteriormente apresentado é completado com a indicação destas duas leis.

Passamos agora a considerar a situação atual dos servidores do Govêrno Brasileiro, referindo-nos mais especialmente aos titulados de carreiras profissionais; conforme já tivemos ocasião de mencionar, algumas das observações e conclusões aplicam-se tambem a outros tipos de empregados do Govêrno.

17) Os funcionários públicos são remunerados pelos seus cargos aos quais correspondem vencimentos fixos; podem também receber quotas ou percentagens, ou remuneração para representação, ou ainda gratificações 
(Estatuto, art. 107 e seguintes). Estas últimas podem ser devidas a diversas causas (idem, art. 120 e seguintes), tais como:

- exercício em determinadas zonas ou locais;

- execução de trabalho de natureza especial;

- prestação de serviço extraordinário;

- elaboração ou execução de trabalhos técnicos ou científicos;

- como componente de órgão legal de deliberação coletiva, ou em função de confiança do Govêrno, ou ainda para serviço ou estudo no estrangeiro.

18) Uma das características da atual legislação brasileira é a distinção nítida entre o cargo e a função.

Em outros tempos, grande número de nomeações era feito para determinadas funções (ex.: para engenheiro-residente, para chefe de depósito, para chefe de oficinas, etc., nas ferrovias); hoje, a não ser para cargos em comissão (diretor, etc.) e para alguns casos especiais (professores, etc.) de lugares efetivos, a nomeação é feita para um certo cargo, ao qual podem corresponder funções variadas (ex.: o ocupante de um lugar de engenheiro em uma estrada de ferro pode desempenhar as funções de engenheiro residente, chefe de depósito, chefe de oficinas, inspetor de sinalização, etc.).

Em alguns casos à função corresponde uma gratificação conforme já indicámos.

19) Outra característica do sistema em vigor é a formação de carreiras, cujos postos sucessivos são preenchidos por promoção e não por nomeação, como acontecia antigamente.

A nomeação para o cargo inicial é agora feita após concurso, o que tambem se verificava algumas vezes no regime antigo, porém de modo irregular e em número reduzido de casos.

20) Consideremos agora a situação atual de um empregado público, nomeado para o cargo inicial de uma carreira, após o seu concurso regular.

A sua remuneração tem um mínimo, que é o vencimento correspondente ao cargo para o qual foi nomeado, na hipótese de que não venha a sofrer descontos por faltas ao serviço ou outras irregularidades.

Êsse mínimo será pago ao empregado qualquer que seja a sua função, a qual, conforme já indicamos, pode variar bastante.

É possível que o empregado receba, além do seu vencimento, uma gratificação, a qual será sempre de natureza transitória, mantendo-se fixa a remuneração do cargo.

Analisando as duas espécies de remuneração, o vencimento e a gratificação, podemos dizer que o primeiro corresponde às credenciais do empregado, 
reveladas em concurso (e futuramente na sua vida funcional, após promoções); enquanto que a gratificação que depende da função, é relativa à sua atividade presente, com as responsabilidades e deveres do serviço que o empregado está realmente desempenhando.

Devemos notar que, atualmente, as funções gratificadas são relativamente muito poucas, e que grande número de empregados, da mesma carreira, recebe vencimentos iguais estando na verdade no desempenho de serviços muito diversos - em alguns casos com encargos de chefia e direção e em outros como simples auxiliares.

Ao que nos parece, pelas considerações que mais adiante desenvolveremos, o número de funções gratificadas deve ser bastante aumentado, para se tornar equitativo.

\section{A promoção}

21) A melhoria permanente das condições de um empregado faz-se normalmente pela promoção, pela qual é o funcionário transferido de um cargo para outro de vencimento imediatamente superior, dentro da mesma carreira.

A promoção está sujeita primeiramente à existência de vaga na classe à qual vai ser promovido o empregado; existindo tal vaga, faz-se a promoção obedecendo alternadamente a dois critérios: o de antiguidade e o de merecimento.

Examinaremos rapidamente cada um destes critérios: o de antiguidade, o de merecimento e ainda o de existência de vaga.

\section{Critério de antiguidade}

22) A promoção por antiguidade pode ser justificada por algumas das seguintes razões:

a) o reconhecimento, por parte do Estado, de que o empregado se valoriza com o tempo de serviço, do qual tem cada vez melhor conhecimento que permite ser cada vez mais eficiente a sua ação.

b) o reconhecimento de que, à medida que passam os anos, tem o empregado necessidade de melhor remuneração devido ao aumento de suas responsabilidades com a família, educação e sustento dos filhos, etc.

Observemos que o critério a) da valorização do empregado com o tempo implica na verdade no reconhecimento de que o seu merecimento aumenta; e si a promoção se dá por antiguidade e não por merecimento, é isto devido ao fato de não ser bastante preciso o mecanismo de avaliação do merecimento. 
Quanto ao critério b) do aumento da necessidades com o tempo - podemos observar que nele, implícita, está a suposição de que a remuneração do funcionário é aproximadamente a necessária e indispensavel para a sua manutenção, sem dar margem a folgas nos orçamentos particulares. (Veja-se o § 4).

\section{Critério do merecimento}

23) Êste critério baseia-se na hipótese de que o empregado que possue merecimento superior ao de seus colegas tem direito a uma melhoria mais rápida do que si fôsse seguido somente o critério da antiguidade. A promoção por merecimento corresponde a uma aceleração na carreira funcional.

Para avaliação do merecimento no serviço público brasileiro existe um sistema especial, do qual já tratámos rapidamente ( $\$ 13$ e 14). Êsse sistema baseia-se no julgamento dos chefes imediatos, através de boletins de merecimento expedidos de quatro em quatro meses e controlados pelas Comissões de Eficiência respectivas. $\mathrm{O}$ critério para julgamento dêsses boletins, para a contagem dos pontos, para as médias de vários boletins, tem sofrido modificações que alteram as classificações dos empregados por ordem de merecimento.

\section{Critério da vaga}

24) Conforme indicámos acima, a promoção por antiguidade é justificada por uma ou outra de duas razões: o aperfeiçoamento do empregado com o tempo de serviço, ou a necessidade de melhor remunerá-lo à medida que envelhece.

Devemos observar que ambas estas razões são baseadas no decorrer do tempo; e que nenhuma delas justifica que se aguarde vaga para promoção do empregado.

A promoção por merecimento, feita em vista dos méritos do funcionário, avaliados êstes por um processo qualquer, não apresenta tambem justificativas para que se espere a ocorrência de vaga. Com efeito, si o empregado já merece ser melhorado na sua remuneração, por que retardar essa melhoria?

O critério da vaga procede de duas origens diversas.

A primeira é a de que tal critério é plenamente justificado em se tratando de funções; neste caso, na verdade, ao atribuir a um empregado encargos mais pesados, é justo remunerá-lo melhor: o número de funções em um serviço devendo ser mantido dentro de certos limites, o critério da vaga se impõe.

Conforme já vimos, antes da organização vigente do serviço público, grande parte das nomeações era feita para funções determinadas, justificando-se assim aguardar a existência de vagas. Essa razão, diante do sistema atual, é puramente histórica, pois neste as promoções não são para funções e sim para cargos diferentes. 
A segunda origem do critério da vaga exige estudo mais acurado, e as suas razões determinantes persistem ainda hoje: é necessário manter os quadros de funcionalismo dentro de certos limites, de modo a evitar abusos e evitar tambem que sejam introduzidas variações bruscas nas verbas orçamentárias.

\section{Promoções e vagas}

25) É facil ver que, si fôssem promovidos imediatamente os empregados, por antiguidade após um determinado número de anos de serviço, e por merecimento logo que a sua eficiência atingisse grau satisfatório, a despesa com os quadros de pessoal deveria flutuar de ano para ano. À primeira vista, parece tambem que as despesas deveriam ir aumentando, porém um exame mais detalhado permite verificar que o aumento real de despesas é relativamente pequeno. Cada ano são verificadas vagas em vários serviços, por aposentadoria, morte ou invalidez; a essas vagas correspondem reduções de despesa no serviço ativo, reduções estas que, no regime vigente, devem ser eliminadas com promoções e novas nomeações.

Dentro de um quadro reduzido, o número anual de vagas pode variar bastante, de modo que deveríamos ter uma variação sensível na despesa de um ano para outro; considerado, porém, o serviço público em conjunto, êsse número de vagas deve ser aproximadamente constante, bem como a despesa total com o funcionalismo.

O método de aumentar os vencimentos dos empregados com o tempo de serviço, independentemente de vagas ou promoções, já foi usado na Prefeitura do Distrito Federal largamente, estando agora limitado aos cargos isolados (sem acesso); o aumento era feito de dois em dois anos. O Banco do Brasil mantem êsse sistema, proporcionando aos empregados aumentos cada cinco anos.

Consideremos primeiramente as promoções por antiguidade.

Dentro de um determinado ano, efetua-se um certo número de promoções por antiguidade, de acordo com a legislação em vigor; a estas promoções corresponde uma certa verba; si considerarmos a antiguidade, não mais dentro de cada quadro isolado, mas em todos os serviços públicos em conjunto, e si as promoções por antiguidade forem efetuadas segundo uma lista geral de antiguidade, os nomes dos funcionários a promover serão em muitos casos diversos dos que são promovidos com o regime atual; o número dêsses empregados, no entanto, e a despesa correspondente serão os mesmos. Não haverá evidentemente aumento algum de despesa e as promoções recairão em empregados realmente mais antigos. Serão também eliminadas as diferenças, 
por vezes grandes e injustas, que existem entre as possibilidades de acesso nos diversos quadros. Êste é um dos argumentos a favor da unificação ou fusão dos quadros do funcionalismo.

Como o número total de vagas anuais é grande, e é muito grande em relação a cada quadro particular, a promoção por antiguidade recairá nos empregados quando estes tiverem aproximadamente o mesmo número de anos de serviço; com uma conveniente proporcionalidade entre os números de lugares de cada classe ou padrão de vencimentos, podemos chegar a um intervalo médio entre promoções capaz de corresponder com bastante exatidão à necessidade de aumento periódico de vencimentos (§22).

As considerações que acabamos de fazer, relativas à antiguidade, conduzemnos, pois, às seguintes sugestões:

a) organização de um quadro único para todos os serviços públicos, no qual, dentro de cada classe ou padrão de vencimentos, sejam classificados todos os empregados públicos, em ordem de antiguidade;

b) reunião de todas as vagas de cada padrão de vencimentos em um grupo único, sendo estas preenchidas com os empregados mais antigos de padrão imediatamente inferior, qualquer que seja o serviço em que se haja verificado a vaga ou em que esteja lotado o funcionário;

c) para cada carreira pode ser fixado - como atualmente - o padrão máximo de vencimentos, além do qual o empregado não será mais promovido.

É certo que, em algumas carreiras, especialmente nas técnicas, o ingresso só é possível para empregados de mais idade do que em outras: comparem-se, por exemplo, as carreiras de engenheiro e de datilógrafo, de médico e de contínuo. Isto, porém, é corrigido perfeitamente, no quadro único, com o estabelecimento de padrões diferentes para as classes iniciais das diversas carreiras, o que já se verifica.

Consideremos agora as promoções por merecimento.

A organização de uma lista geral de antiguidade é possível; maiores dificuldades apresenta a organização de uma lista geral de merecimento; e isto devido à grande dificuldade da avaliação do merecimento.

Dentro dos próprios serviços varia o critério de julgamento conforme o chefe de serviço, o que é inevitável, apesar de todos os esforços continuados feitos pelo Departamento Administrativo do Serviço Público e pelas Comissões de Eficiência para uniformização dêsse critério, do qual depende, em última análise, toda a eficácia do atual método de boletins de merecimento.

Cumpre observar, todavia, que, si tal dificuldade existe, não é ela inerente a um sistema que tivesse por objetivo a organização de listas gerais de merecimento, 
abrangendo todos os serviços, em lugar de listas isoladas, para cada serviço, como atualmente. Argumentar que as listas isoladas correspondem a um sistema mais justo seria reconhecer que a avaliação do merecimento é imperfeita.

Parece assim que, para maior equidade nos serviços públicos, é aconselhavel a reunião de todos os diferentes quadros em um único. Isto pode naturalmente ser efetuado por etapas, fundindo primeiramente alguns quadros em grupos determinados, passando depois à fusão dêsses grupos.

Esta questão tem certamente várias soluções, cada uma com méritos e desvantagens próprios; a seguir, considerando principalmente a organização das carreiras profissionais, apresentamos uma solução que pouco se afasta da que atualmente vigora no que se refere a promoções por antiguidade, pois a única alteração é a relativa à organização de um quadro único. A parte relativa a merecimento é, no entanto, totalmente diferente, parecendo-nos mais simples e mais exata na distinção dos empregados mais eficientes.

\section{Sugestões sôbre a organização das carreiras}

26) A solução que sugerimos baseia-se em atribuir importância maior às funções. Observemos de início que não pode haver melhor prova do merecimento e da eficiência de um empregado do que a sua designação e a sua permanência em função mais trabalhosa, de maior responsabilidade e maior importância do que as desempenhadas pelos seus colegas.

Considerando, por exemplo, a carreira de agentes de estação de estrada de ferro, não é mais justo promover aqueles que estão encarregados das funções de chefe de estação do que os classificados como ajudantes? E não é claro que maior merecimento têm os que trabalham nas estações de maior movimento ou situadas em zonas mais ingratas?

No sistema atual, é possível fazer distinção entre tais casos de merecimento diferente, porém esta distinção envolve a questão de critério de julgamento a que já nos referimos, critério frequentemente falho quando exercido por várias pessoas de atribuições semelhantes, encarregadas do preenchimento dos boletins de merecimento.

Sendo um determinado empregado julgado apto para o desempenho de funções mais trabalhosas ou de maior responsabilidade do que os seus colegas, e de tal função se desincumbindo corretamente, que necessidade ha ainda de estabelecer em pontos o seu maior merecimento? Não é a própria função o melhor atestado do valor do empregado? 
No caso de funções elevadas, como, em uma estrada de ferro, são as de chefe de divisão ou assistente de divisão, quando tais funções cabem a engenheiros de determinado padrão de vencimentos, padrão êste que é o mesmo de outros engenheiros encarregados de funções menos importantes, parece claro que o engenheiro encarregado da função mais importante deve ter merecimento superior ao dos demais; no caso considerado, seria o engenheiro que estivesse desempenhando as funções de chefe de divisão. Isto no entanto não é verificado no sistema atual: o engenheiro assistente obterá frequentemente graus máximos, já pela sua atuação satisfatória, já pelo fato do seu chefe e colega - de mesmo padrão de vencimentos - se julgar tolhido na sua liberdade de reduzir os pontos do assistente; o chefe de divisão obterá tambem graus máximos, conferidos pelo diretor do serviço. Os dois funcionários entrarão assim com o mesmo número de pontos na lista de merecimento, da qual poderão fazer parte tambem outros funcionários ainda com o mesmo número de pontos embora encarregados de funções de menor importância que os dois acima indicados. Pelo sistema atual o desempate será feito pela antiguidade (tendo sido recentemente suprimidos outros meios que permitiam o desempate, tais como monografias sôbre serviço público, títulos oficiais, etc.); e assim o funcionário encarregado da função mais importante - no caso o chefe de divisão - poderá até mesmo deixar de ser incluído na lista para promoção. Tal caso já foi observado na realidade.

Podemos assim dizer que o sistema atual apresenta falhas; e do seu exame vemos que tais falhas residem no fato de não ser dada a devida importância às funções na organização dos boletins de merecimento.

Suponhamos agora que, para um determinado serviço, a cada função é atribuído um determinado padrão de remuneração, tarefa esta que deve competir aos diretores do serviço em causa e à Comissão de Eficiência respectiva. Admitamos que tais funções são exercidas por titulados de diversos padrões de vencimento (relativos aos seus cargos efetivos). Os padrões das funções podem ser, para maior simplicidade, organizados segundo a mesma tabela adotada para os padrões de vencimentos.

Ha três possibilidades a considerar, em vista do padrão do cargo e do padrão da função de um determinado empregado.

1ํ) $O$ padrão do cargo é inferior ao da função.

A ser remunerado somente com o vencimento do seu cargo, o empregado não estará sendo pago de acôrdo com o seu trabalho; é portanto justo que Ihe seja paga tambem a diferença entre o vencimento relativo ao cargo e o padrão de remuneração da função: assim um empregado padrão K desempenhando uma 
função padrão $L$ terá direito a uma diferença de vencimentos de 2:300\$0 - 1:900\$0 $=400 \$ 0$ mensais.

Êsse empregado, mantendo satisfatório desempenho da sua função dentro de um certo prazo, fará jús a uma promoção por merecimento. Efetivada esta, e caso o seu novo cargo seja agora de padrão igual ao da função, deixará o empregado de receber a diferença de vencimentos; deixará tambem de fazer jús a nova promoção por merecimento, recaindo então no caso seguinte.

2) O padrão do cargo é igual ao da função.

Neste caso o empregado será pago de acordo com o seu trabalho; não terá direito a promoção por merecimento e deverá aguardar a promoção por antiguidade.

3ㅇ) O padrão do cargo é superior ao da função.

O empregado recebe mais do que vale o seu trabalho atual.

Sendo, no entanto, a remuneração do cargo correspondente aos antecedentes do funcionário, conforme fizemos notar em capítulo anterior (§ 20), êste caso não traduz uma injustiça.

Poderá tratar-se de um empregado com vários anos de serviço e, conforme já vimos tambem, o sistema de promoções por antiguidade reconhece que é justo remunerar melhor os empregados à medida que aumentam os seus anos de serviço. O princípio da aposentadoria remunerada, consagrado na Constituição, reconhece tambem o direito adquirido pelo empregado durante os seus anos de serviço: si é possivel pagá-lo quando já não trabalha, por que não será possivel remunerá-lo um pouco acima do seu trabalho atual, depois de já ter vários anos de bons serviços?

O sistema que acima esboçamos parece-nos mais justo e equitativo que o atual, e muito mais capaz de estimular os empregados, não somente pelo fato de melhor remunerá-los quando em desempenho de funções mais elevadas, como tambem porque acelera a promoção dos que mais trabalham.

A tal sistema pode se apresentar a crítica de não permitir a manutenção da despesa de pessoal titulado dentro de limites tão rígidos quanto o sistema atual. Si observarmos, no entanto, que as vagas dos quadros efetivos devem ser preenchidas, por merecimento, pelos empregados que recebem diferenças de vencimentos entre o padrão do cargo e o da função, verificaremos que a verba de pessoal tende a reajustar-se automaticamente. Ademais, si são admissiveis oscilações nas verbas de extranumerários, para não falar aqui das verbas de material, por que não admiti-las, em pequena escala, no pagamento dos titulados? 


\section{Resumo da organização sugerida para carreiras profissionais}

27) Reunimos a seguir os princípios de organização que esboçámos e que, conforme já foi indicado, são destinados especialmente aos titulados das carreiras profissionais, mas que poderiam ser aplicados em outros casos tambem.

I) O serviço será desempenhado por funcionários, cuja nomeação e cujos direitos e deveres são indicados no Estatuto dos Funcionários Públicos Civis.

II) Cada funcionário possue um cargo efetivo ao qual corresponde um padrão de vencimentos; a reunião dos empregados de mesmo padrão de vencimentos constitue a classe; o conjunto de classes sucessivas, em ordem crescente de padrões de vencimentos, constitue a carreira.

Para o efeito de promoções, todas as classes de mesmo padrão de vencimentos, dentro de cada serviço ou repartição, e de todos os serviços ou repartições em conjunto, serão reunidas em classes únicas, cujo conjunto constituirá o quadro único do funcionalismo público civil.

III) Para cada carreira serão fixados os cargos respectivos, do inicial ao final, além do qual os funcionários não poderão ser promovidos.

IV) Em cada serviço público, as funções serão classificadas, de acôrdo com a sua importância, responsabilidade e exigências técnicas, em padrões fixos, análogos aos já adotados para os cargos. Tal classificação será feita pelas Comissões de Eficiência, diante das informações dos chefes de serviço.

Às Comissões de Eficiência compete a revisão permanente dessa classificação de funções. Aos chefes de serviço cabe indicar e solicitar as alterações necessárias.

V) A cada função corresponderá, pois, um padrão de remuneração.

O funcionário designado para cada função poderá ser de cargo cujo padrão de vencimentos seja inferior, igual ou superior ao padrão da função.

Caso o padrão do cargo seja inferior ao da função, o funcionário receberá como diferença de vencimentos a importância correspondente à diferença entre o padrão do seu cargo e o da sua função.

Caso o padrão do cargo seja igual ou superior ao da função, o empregado receberá somente o vencimento relativo ao seu cargo.

VI) As promoções serão feitas alternadamente por antiguidade e por merecimento.

VII) As promoções por antiguidade recairão automaticamente no funcionário mais antigo em cada classe.

VIII) A promoção por merecimento recairá no funcionário escolhido pelo Presidente da República dentre os que figurarem na lista de concorrentes 
organizada pelo D.A.S.P., de acôrdo com os elementos fornecidos pelas Comissões de Eficiência dos diversos Ministérios.

Só poderão ser promovidos por merecimento os funcionários que estiverem desempenhando funções de padrão superior ao do seu cargo efetivo, ha mais de 365 dias.

Caso não haja funcionário nessas condições, a vaga respectiva será preenchida por antiguidade.

A classificação por merecimento será feita na seguinte ordem:

1ํ) o funcionário que estiver desempenhando função de padrão mais elevado;

2) em face de igualdade na condição acima, o primeiro colocado será o que estiver ha mais tempo no desempenho da função elevada;

3) ainda em caso de igualdade, o desempate será feito sucessivamente:

- pelos títulos oficiais de cada funcionário, homologados pelas Comissões de Eficiência;

- pela antiguidade de classe;

- pelo tempo de serviço.

\section{V - Possibilidade de acesso nas carreiras profissionais}

\section{8) Definições da possibilidade de acesso}

Já fizemos notar no início dêste estudo que o fundamento de uma carreira está na remuneração correspondente aos postos sucessivos sôbre a qual tivemos oportunidade de apresentar algumas sugestões.

Vamos agora considerar a questão do acesso nas carreiras profissionais, a qual é tão importante quanto a da fixação dos vencimentos ou ordenados correspondentes às classes componentes de uma carreira.

Dentro de uma destas, o acesso, ou seja a mudança do funcionário de um cargo para outro de mais elevado padrão de vencimentos, só é possível pela promoção. Desta e dos critérios a que está ou pode estar subordinada já nos ocupámos. O problema vai agora ser considerado sob outro aspecto, que é o da determinação das possibilidades de acesso; êste aspecto é acentuadamente matemáticoestatístico; nele devemos supor tipos ideais de funcionários que, no caso mais geral, serão imaginados como possuindo todos as mesmas aptidões e a mesma eficiência funcional dentro de uma mesma classe.

Desaparece assim a diferença entre a promoção por antiguidade e a promoção por merecimento; não são considerados, nem o estudo analítico comporta tais cousas, os 
casos de merecimento excepcional ou inferior; o que resta para o cálculo é o número de funcionários de cada classe, a quantidade média ou provavel de vagas em que êstes podem ser promovidos e o tempo necessário para a ocorrência dessas vagas.

O estudo que se segue aplica-se, portanto, a qualquer tipo de quadro, aos atualmente existentes ou aos do tipo que sugerimos; desde que tais quadros sejam de carreira e que a passagem de uma classe para outra imediatamente superior só possa ser feita por promoção.

A possibilidade de acesso para os funcionários de uma determinada classe de uma certa carreira pode ser definida pelo número de vagas que podem ser preenchidas com funcionários da classe considerada, na classe imediatamente superior, em um prazo determinado. Isto corresponde à possibilidade de acesso à classe imediatamente superior.

Tal possibilidade pode tambem ser definida, evidentemente, pelo intervalo médio ou provavel entre duas promoções consecutivas dos funcionários de uma classe para a imediatamente superior.

Considerada a carreira em conjunto, com as suas diversas classes, a possibilidade de acesso pode ser interpretada através dos números de empregados da classe inicial que poderão chegar a cada uma das diversas outras classes, da imediatamente superior à inicial até a classe final da carreira, dentro de um número determinado de anos.

Pode-se ainda considerar a possibilidade de acesso como definida pelo tempo médio necessário para que um empregado de uma determinada classe atinja uma outra classe qualquer, superior àquela em que está.

O estudo teórico refere-se, pois, sempre a números médios ou provaveis; as condições impostas pelas leis ou regulamentos e pelos limites da vida humana permitem estabelecer outros números, mínimos e máximos. Assim é que, em face da exigência legal do interstício de dois anos entre duas promoções consecutivas de um mesmo funcionário, o tempo mínimo necessário para passar da classe inicial à final de uma carreira de quatro classes é de seis anos. Sendo de vinte e um anos, por exemplo, a idade mínima para ingresso em determinada carreira e de sessenta e oito anos o limite de idade para serviço, o tempo máximo de que um funcionário poderá dispor para passar da classe inicial à final será de quarenta e sete anos.

\section{9) Vagas e promoções}

Seja $a$ a classe inicial de uma carreira, $b, c, d . .$. as classes seguintes em ordem ascendente, $i$ uma classe intermédia qualquer, $k$ a penúltima classe e $I$ a classe final.

O número de lugares de cada classe é respectivamente 


$$
N_{a^{\prime}}, N_{b^{\prime}}, N_{c} \ldots N_{1} \ldots N_{j^{\prime}}, N_{k^{\prime}}, N_{1}
$$

Dentro de um determinado período $T$ anos verificam-se $V_{1}$ vagas na classe $l ; V_{1}$ funcionários podem ser promovidos da classe $k$ para a classe $I$.

No mesmo período $T$, verificam-se $\mathrm{V}_{\mathrm{k}}$ vagas na classe $k$; o número de funcionários da classe $j$ que podem ser promovidos à classe $k$ é

$$
\mathrm{V}_{\mathrm{k}}+\mathrm{V}_{1}
$$

O número total de funcionários que podem ser promovidos da classe inicial à classe imediatamente seguinte $b$ é portanto:

$$
\mathrm{V}_{\mathrm{b}}+\mathrm{V}_{c} \ldots+\mathrm{V}_{\mathrm{i}} \ldots+\mathrm{V}_{\mathrm{k}}+\mathrm{V}_{1}
$$

dentro do período $T$.

Ou, simbólicamente:

$$
P_{a b}=\Sigma_{b}^{l} \quad v_{i}
$$

e tambem

$$
P_{i j}=\Sigma_{d}^{\prime} v
$$

que é a expressão geral do número de promoções $P_{i j}$ de empregados de uma classe qualquer $i$ à classe imediatamente superior $j$, dentro do período $T$.

$\mathrm{O}$ número $\mathrm{V}_{\mathrm{j}}$ de vagas em uma classe qualquer $j$, dentro de um período $T$ anos pode ser calculado pelas tabelas de mortalidade e sobrevivência e pelas condições relativas a aposentadarias.

O número total de vagas na classe final da carreira é igual ao número de vagas por morte ou invalidez mais o número de vagas por aposentadoria.

Nas classes intermédias, ou na inicial, conforme já indicamos, o número de vagas é a soma das vagas verificadas na classe considerada com as vagas verificadas nas classes superiores.

\section{0) Probabilidade de promoção}

Durante o período considerado $T$ verificam-se $V_{k}$ vagas na classe $k$ : o número de funcionários da classe $k$ que concorre às promoções é pois $N_{k}-V_{k^{\prime}}$; em cada promoção de $k$ para l a probabilidade de promoção de cada empregado é

$$
\frac{l}{N_{k}-v_{k}}
$$


No período $T$, havendo $V_{1}$ promoções de $k$ para $I$, a probabilidade de promoção de cada funcionário de $k$ para I nesse período será

$$
\frac{V_{1}}{N_{k}-V_{k}}
$$

A probabilidade de promoção da classe $i$ para a classe $j$ é analogamente

$$
(r)_{i j}=\frac{\Sigma_{d}^{\prime}}{N_{i}-v_{i}}=\frac{P_{i j}}{N_{i}-v_{i}}
$$

sendo esta a expressão geral da probabilidade de promoção, $(\Upsilon)_{i j}$ de um empregado da classe $i$ para a subsequente $j$ no período $T$.

Observação - A probabilidade deve variar de zero (impossibilidade) a um (certeza). Si o intervalo $T$ é grande, o número de promoções $P_{i j}$ pode ser igual a $\left(N_{1}-V_{1}\right)$, o que indica a certeza da promoção dentro do período considerado. Si êste é excessivamente grande, $P_{i j}$ pode ser maior do que $\left(N_{1}-V_{1}\right)$, o que corresponderia a uma probabilidade maior do que um. Neste caso a fórmula (3) não tem significação. Este inconveniente desaparece com a consideração de períodos adequados, ou com o cálculo baseado nos intervalos médios entre promoções, conforme veremos a seguir.

\section{1) Número médio anual de promoções}

Verificando-se $V_{1}$ vagas na classe I no período $T$ anos, a quantidade média de vagas por ano é

$$
m_{k l}=\frac{V_{1}}{T}
$$

que exprime tambem o número médio anual de promoções da classe $k$ para a classe $l$.

Analogamente, o número médio anual de promoções da classe $i$ para $j$ é

$$
m_{i j}=\frac{\Sigma_{j}^{\prime} v}{T}-\frac{P_{i j}}{T}
$$

\section{2) Intervalo médio entre promoções}

Havendo $V_{1}$ promoções de $k$ para I em $T$ anos, o intervalo médio entre duas promoções consecutivas de $k$ para $/$ é

$$
t_{k e}=\frac{T}{V_{1}}=\frac{1}{m_{k l}}
$$


Igualmente temos

$$
t_{i j}=\frac{T}{\Sigma_{j}^{\prime} v}=\frac{T}{P_{i j}}=\frac{1}{m_{i j}}
$$

para expressão do intervalo médio entre duas promoções consecutivas da classe $i$ para $j$.

\section{3) Tempo médio de permanência em uma classe}

As promoções de uma certa classe $i$ para a classe imediatamente superior $j$ seguem-se com intervalos médios $t_{i j}$.

Tomando a época de uma promoção para origem dos tempos, haverá outra promoção depois de um tempo $t_{i j}$; depois de um tempo $2 t_{i}$, haverá outra promoção, etc.

O primeiro empregado promovido (não contando o que foi promovido no tempo zero) deve, pois, esperar um tempo $t_{i j}$, o segundo promovido deve esperar um tempo $2 t_{i j}$ etc.; o último promovido terá que esperar um tempo $N_{i} \cdot t_{i j}$ na hipótese de que todos os empregados da classe $i$ sejam promovidos a $j$.

Devendo verificar-se, no entanto, $V_{i}$ vagas na classe $i$, o número de empregados promovidos de $i$ para $j$ não será $N_{i}$ e $\operatorname{sim}\left(N_{i}-V_{i}\right)$; neste caso o último empregado a ser promovido deve esperar um tempo

$$
\left(N_{l}-V_{l}\right) \cdot t_{i j}
$$

A média dos tempos de espera é, pois

$$
\begin{aligned}
\theta_{i j}= & \frac{t_{i j}+2 t_{i j}+3 t_{i j}+\ldots+\left(N_{i}-V_{i}\right) t_{i j}=}{N_{i}-N_{i}} \\
& =\frac{t_{i j}}{N_{i}-V_{i}} \cdot\left[1+2+3+\ldots+\left(N_{i}-V_{i}\right)\right]= \\
& =\frac{t_{i j}}{N_{i}-V_{i}} \cdot \frac{\left(N_{i}-V_{i}\right)\left(N_{i}-V_{i}\right)+1}{2} \\
& =\frac{t_{i j}}{2} \cdot\left(N_{i}-V_{i}+1\right)
\end{aligned}
$$


Esta fórmula indica o tempo médio necessário para que um empregado seja promovido da classe i para a classe $j$, ou seja, o tempo médio de permanência na classe considerada $i$.

34) Tempo necessário para promoções sucessivas de um mesmo empregado de uma classe para outra qualquer

Conhecidos os tempos médios

$$
\theta_{a b}, \theta_{b c}, \ldots \theta_{j k}, \theta_{k l}
$$

que um empregado deve permanecer em cada classe, é fácil calcular o tempo total necessário para passar de uma classe para outra qualquer:

$$
\theta_{i k}=\theta_{i j}+\theta_{j k}
$$

Em particular, da classe inicial para a final temos

$$
\theta_{a l}=\theta_{a b}+\theta_{b c}+\ldots+\theta_{j k}+\theta_{k l}
$$

\section{5) Número de empregados que podem atingir a classe final}

Sendo $\mathrm{W}$ a vida média funcional de cada empregado da classe inicial até a final, a proporção de empregados que chegarão à classe final será

$$
r=\frac{w}{\theta_{a l}}
$$

\section{6) Método de cálculo}

Consideremos agora uma carreira já constituída ha algum tempo, que é o caso mais geral.

Temos que levar em conta as possibilidades de acésso dos empregados que já a integram e as de cada novo empregado que nela ingressar: o ingresso destes novos empregados só sendo possivel na classe inicial. Não é, portanto, levada em linha de conta a possibilidade de transferência de uma carreira para outra, possibilidade esta aliás praticamente muito reduzida.

a) pela aposentadoria compulsória (aos 68 anos de idade)

b) pela aposentadoria facultativa, ao serem completados 35 anos de serviço;

c) pela morte; o número provavel de vagas correspondentes pode ser calculado pelas tabelas de sobrevivência e mortalidade. 
II) Conhecido $V_{l}$, tem-se imediatamente o número de promoções $P_{k l}$ da classe ante-final $k$ para a final $l$ :

$$
P_{k l}=\Sigma_{e}^{\prime} \quad V=v_{e}
$$

III) Dentro do prazo $T$ considerado, a probabilidade de acesso $\mathrm{W}_{\mathrm{kl}}$ de $u \mathrm{~m}$ empregado qualquer da classe $k$ para a classe $/$ é

$$
(I)_{k l}=\frac{P_{k l}}{N_{k}-V_{k}}
$$

IV) A quantidade média anual $m_{x i}$ de vagas na classe I, ou o número médio anual de promoções da classe $k$ para a classe $/$ é

$$
m_{k l}=\frac{P_{k l}}{T}
$$

V) O intervalo médio $t_{k l}$ entre duas promoções consecutivas da classe $k$ para / é

$$
t_{k l}=\frac{1}{m_{k l}}
$$

$\mathrm{VI}) \mathrm{O}$ tempo médio $\theta_{k l}$ que um empregado deve aguardar na classe $k$ para ser promovido à classe / é

$$
\theta_{k l}=\frac{t_{k l}}{2}\left(N_{k}-V_{k}+l\right)
$$

$V_{k}$ sendo o número provavel de vagas a se verificar na classe $k$, no período $T$, sendo calculado do mesmo modo que $V_{1}$.

VII) Conhecidos $V_{1}$ e $V_{k^{\prime}}$ números provaveis de vagas entre funcionários das classes $k$ e $l$, pode-se calcular o número de promoções da classe $j$ para $k$

$$
P_{j k}=V_{k}+V_{1}
$$

VIII) Como no caso anterior, a probabilidade de acesso da classe $j$ para $k$ é

$$
(r)_{j k}=\frac{P_{j k}}{N_{j-} V_{j}}
$$

sendo $\mathrm{N}_{\mathrm{J}}$ o número de ocupantes da classe $j$.

A quantidade média anual de vagas na classe $k$, ou o número médio anual de promoções de $j$ para $k$ é 


$$
m_{j k}=\frac{P_{j k}}{T}
$$

IX) A repetição do processo acima permite chegar até os números correspondentes à classe inicial.

X) Conhecidos os tempos médios $\theta_{\mathrm{ab}}, \theta_{\mathrm{bc}}, \ldots \theta_{\mathrm{kl}}$ de permanência em cada classe, o tempo médio total necessário para que um mesmo empregado passe da classe inicial para a final é

$$
\theta_{a l}=\theta_{a b}+\theta_{b c}+\ldots+\theta_{k l}
$$

fórmula pela qual se pode tambem calcular o tempo necessário para passar de uma classe qualquer para outra qualquer.

XI) A percentagem de empregados da classe inicial que atingem a final é

$$
r=\frac{W}{\theta_{a l}} \times 100
$$

Nota: Mais adiante são apresentados alguns exemplos dêstes cálculos.

\section{7) Observações sôbre o cálculo}

Para calcular as aposentadorias compulsórias e a mortalidade é necessário o conhecimento das idades dos diversos funcionários; êste dado em geral não figura nas tabelas de antiguidade publicadas de acôrdo com a lei, das quais constam somente o tempo de classe e o tempo total de serviço. A idade pode ser obtida aparelhando-se convenientemente o serviço de pessoal para esse fim. $\mathrm{Na}$ falta dêste elemento, e possuindo as listas de antiguidade, bem como aproximadamente a idade de ingresso na classe inicial da carreira, é possível calcular com certa aproximação a idade de cada empregado, e com êste dado obter o tempo necessário para aposentadoria, bem como os dados que figuram nas tabelas de sobrevivência e mortalidade.

38) Os princípios apresentados e as tabelas estatísticas permitem determinar tambem a proporção que deve existir entre o número de lugares de cada uma das classes de uma determinada carreira.

É razoavel admitir que todos os empregados da classe inicial de uma carreira possam atingir a uma determinada classe, cuja remuneração seja suficiente para as necessidades do sustento de uma família normal; os quadros devem, pois, ser organizados de modo que todos os empregados que não tenham a sua carreira interrompida pela morte ou outro motivo possam chegar a essa determinada 
classe, que não é necessariamente a classe final. Tal classe deve ser determinada à vista das estatísticas de custo de vida.

Dessa classe intermédia, à qual todos poderão atingir, até a classe inicial, podem as promoções ser calculadas em face das tabelas de sobrevivência e mortalidade; da classe intermédia considerada até à final devem ser obedecidos outros critérios.

$\mathrm{Na}$ legislação atual as promoções são feitas por antiguidade e por merecimento até à classe ante-final, e desta para a final por merecimento somente; podemos, portanto, admitir que à classe ante-final é que devem ter acesso todos os funcionários de cada carreira. No cálculo teórico seguinte admitimos este critério, que nada tem de absoluto e que deverá ser modificado de acordo com a espécie das carreiras, o custo da vida, etc.

Suponhamos uma carreira constituída das classes

$$
a, b, c \ldots i, \ldots k, \text { l }
$$

À classe ante-final $k$ deverão poder chegar todos os empregados que ingressam na classe inicial $a$; à classe final poderá chegar somente um certo número de empregados, conforme o critério adotado pelos organizadores da carreira.

Seja $\mathrm{I}_{\mathrm{u}}$ a idade média de ingresso na classe $a$ e seja $\mathrm{I}_{\text {a }}$ idade média de promoção de $k$ para l; o tempo médio de serviço total de cada empregado será

$$
\left(I_{1}-I_{a}\right)+U_{1}
$$

$U$, sendo o tempo médio de permanência na classe I.

O tempo

$I_{1}+U_{1}$ deve ser no máximo igual a 68 anos, que é o limite de idade para serviço ativo.

A idade $I_{u}$ oscila entre 20 e 35 anos.

Existindo $n$ classes, o tempo médio de permanência em cada classe será

$$
\frac{I_{1}-I_{a}+U_{1}}{n}
$$

e si o tempo de permanência na última classe é igual à das outras, temos

$$
\frac{I_{1}-I_{a}+U_{1}}{n}=U_{1}
$$

donde

$$
U_{1}=\frac{I_{1}-I_{n}}{n-1}
$$


ou, sendo

$$
\begin{aligned}
& I_{1}+U_{1}=68 \\
& U_{1}=\frac{68-I_{a}}{n}
\end{aligned}
$$

Conhecido o número de classes, a idade de ingresso e a idade limite (68 anos), podemos calcular o tempo médio de permanência em cada classe, pelas fórmulas (10) ou (11).

Exemplo:

$$
\text { Número de classes } n=6
$$

Idade média de ingresso na classe inicial $\mathrm{I}_{\mathrm{a}}=25$ anos

$$
U_{I}=\frac{68-25}{6}=7.17 \text { anos }
$$

Analogamente podemos obter os valores da tabela seguinte para diversos números de classes na carreira, admitida a idade de ingresso na classe inicial como sendo de 25 anos:

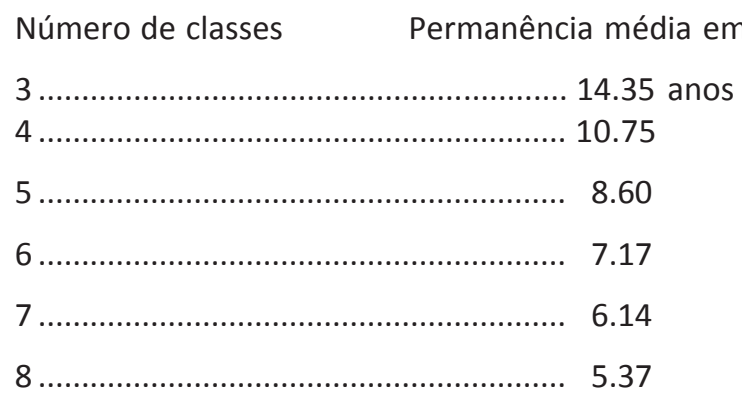

A proporção de lugares em cada classe, em relação à inicial pode ser obtida pelas tabelas de sobrevivência; assim, para uma carreira de 6 classes nas condições acima indicadas, devemos ter para 100 empregados na classe inicial:

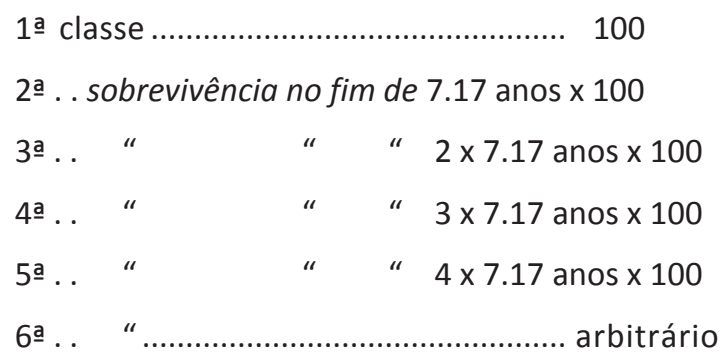




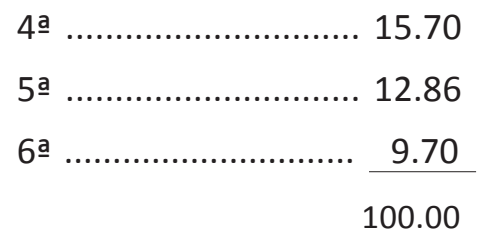

Caso se tenha a organizar um quadro de 120 homens, teremos:

$\begin{array}{lll}\text { 1a classe } & \frac{22.40}{100} \times 120 & \text { aprox. } 27 \\ \text { 2a classe } & \frac{20.70}{100} \times 120 & \text { aprox. } 25 \\ \text { 3a classe } & \frac{18.64}{100} \times 120 & \text { aprox. } 22 \\ \text { 4a classe } & \frac{15.70}{100} \times 120 & \text { aprox. } 19 \\ \text { 5a classe } & \frac{12.86}{100} \times 120 & \text { aprox. } 15 \\ \text { 6a classe } & \frac{9.70}{100} \times 120 & \text { aprox. } \frac{12}{120}\end{array}$

\section{9) Tabelas de sobrevivência e mortalidade}

No exemplo anterior e nas aplicações que se seguem, utilizámos as táboas organizadas por Bulhões Carvalho (Estatística, pag. 281 e seguintes) relativas à sobrevivência e mortalidade no Distrito Federal e em várias capitais de estados brasileiros, as quais são baseadas no recenseamento de 1940.

Novas estatísticas, detalhadas em relação aos locais de trabalho, às categorias sociais e econômicas, permitirão certamente maior aproximação nos cálculos.

Considerando a aproximação que se pode esperar das estatísticas empregadas e dos métodos de cálculos que delineámos, em lugar de considerar as idades dos empregados de ano em ano, considerámos nas aplicações seguintes essas idades divididas em grupos de cinco anos (20-24, 25-29, 30-34 etc.).

Para período de referência ( $T$, §29 e seguintes) adotámos sempre dez anos.

A seguir apresentamos uma tabela de sobrevivência, para idades de 20 a 69 anos, baseada nas de Bulhões Carvalho. Assim, na "Estatística, pag. 281 a 283, "Táboas de sobrevivência e de mortalidade no Distrito Federal e em várias capitais", encontramos:

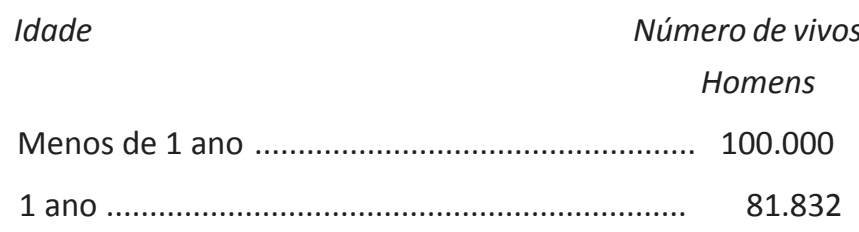




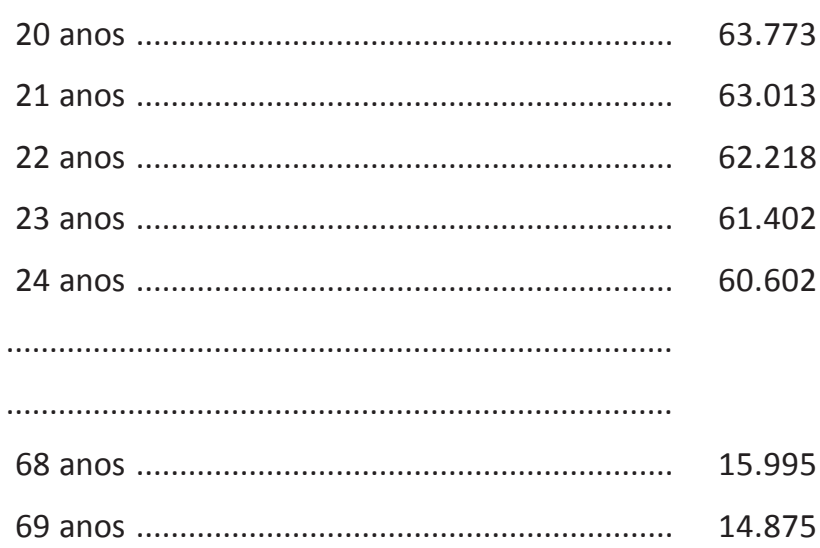

Para o grupo de 20 a 24 anos de idade temos
(20)
63.773
(21)
63.013
(22)
62.218
(23)
61.402
(24)
60.602
Soma
311.008

Média

$311.008: 5=62.202$ vivos

Analogamente calculámos as sobrevivências para os grupos 25-29, 30-34, ... 6569 anos:

\begin{tabular}{|c|c|}
\hline Idade & Sobrevivêncic \\
\hline $20-24$ & ............ 62.202 \\
\hline $25-29$ & 58.115 \\
\hline $30-34$ & ..... 54.642 \\
\hline $35-39$ & $\ldots \quad 50.573$ \\
\hline $40-44$ & $\ldots .46 .096$ \\
\hline $45-49$ & 40.991 \\
\hline $50-54$ & ...... 35.622 \\
\hline $55-59$ & ..... 29.661 \\
\hline
\end{tabular}




e também $\begin{array}{rr}60-64 \ldots \ldots \ldots \ldots \ldots \ldots \ldots \ldots \ldots \ldots \\ 65-69\end{array}$

As diferenças entre as sobrevivências dos diversos grupos permitem calcular a mortalidade durante o tempo necessário para passar de um grupo a outro. Assim, admitindo o período de dez anos, o grupo 20-24 nesses dez anos deve sofrer uma perda

62.202

$\begin{array}{rr}-54.642 & (20-24) \\ 7.560 & (30-24)\end{array}$

Assim, dos vivos entre 20 e 24 anos devem morrer nos próximos dez anos

$$
\frac{7.560}{62.202}=12,16 \%
$$

e devem sobreviver

$$
100.000-12.16=87.84 \%
$$

Análogamente podemos calcular as sobrevivências e mortalidades para cada um dos grupos de cinco anos dentro do período de dez anos mais próximos.

Assim foi organizada a tabela seguinte, que servirá de base para cálculos que se seguem, a título de exemplo.

\begin{tabular}{|c|c|c|}
\hline \multirow[t]{2}{*}{ Idade por grupos } & \multicolumn{2}{|c|}{ No fim de dez anos } \\
\hline & Sobrevivência & Mortalidade \\
\hline $20-24$ anos ........... & $87.84 \%$. & ....... $12.16 \%$ \\
\hline $25-29$ anos $\ldots$. & ... 87.02 . & ....... 12.98 \\
\hline $30-34$ anos .... & 84.90. & ....... 15.10 \\
\hline $35-39$ anos. & 82.74 & ....... 17.26 \\
\hline $40-44$ anos ............ & ..... $77.50 \ldots \ldots$ & ..... 22.50 \\
\hline $45-49$ anos ............ & .. $72.35 \ldots$. & ....... 27.65 \\
\hline $50-54$ anos .. & 65.72 & .... 34.28 \\
\hline $55-59$ anos ...... & $\ldots 57.90 \ldots$ & ...... 42.10 \\
\hline $60-64$ anos & $48.60 \ldots$ & .... 51.40 \\
\hline $5-69$ ano & & \\
\hline
\end{tabular}

\section{Tabela de sobrevivência e mortalidade}




\section{0) Exemplos}

Carreira de Engenheiro, da E. F. Central do Brasil; dados do Boletim do Pessoal, no 98, pag. 2221 e seguintes.

Não possuindo informações precisas sôbre a idade de cada engenheiro, admitiremos que a idade de cada um é igual ao tempo de serviço mais 21 anos (7.670 dias).

Obtemos assim os resultados que se seguem, seguindo o método de cálculo do $\S 36$.

O "Boletim do Pessoal no 98" indica as antiguidades de classe e de serviço até 30 de Abril de 1939. Esta será a data de referência (tempo zéro).

Desse boletim obtemos os seguintes dados:

\section{Classe $\mathbf{N}-$ final}

\begin{tabular}{|c|c|c|}
\hline Tempo de serviço (anos) & Quantidade de empregados & Idade média ( \\
\hline 35 а $39 . . . \ldots \ldots \ldots . . . . . . .$. & 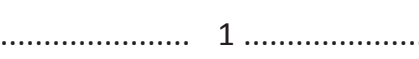 & ................ 58 \\
\hline 30 a $34 \ldots$ & $\ldots . .$. & ............. 53 \\
\hline 25 a $29 \ldots \ldots . .$. & $\ldots \ldots .4 \ldots \ldots$ & ............. 48 \\
\hline 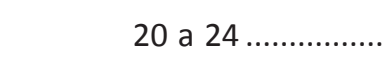 & $\ldots$ & $\ldots$ \\
\hline 15 a $19 \ldots \ldots . .$. & $\ldots \ldots \ldots . .4$ & $\ldots \ldots \ldots \ldots . .38$ \\
\hline 10 a $14 \ldots \ldots . . . .$. & $\ldots . \quad 2 \ldots \ldots$ & ..... 33 \\
\hline 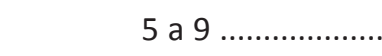 & ........... & - \\
\hline
\end{tabular}

\section{Classe M}

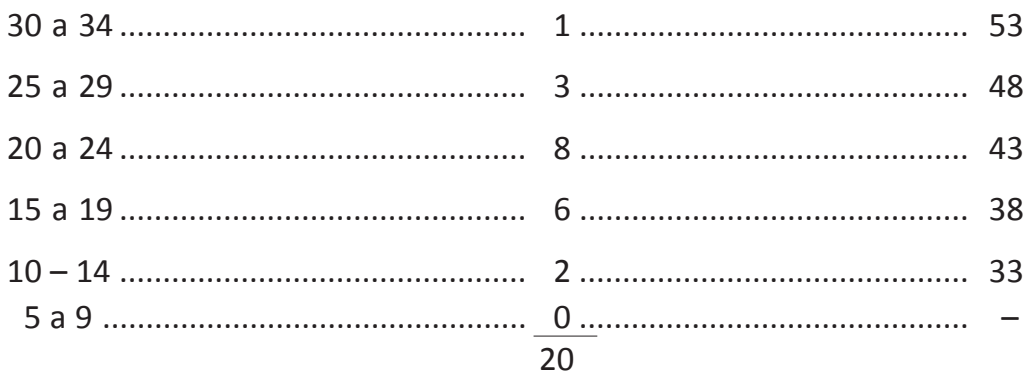

Classe L

35 a 39 0

30 a 34 1 . 53

25 a 29 . 3 48 


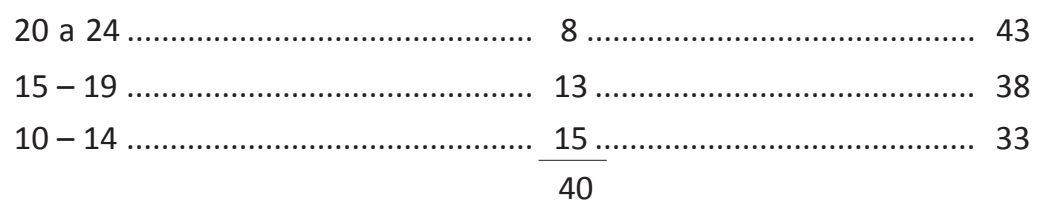

\section{Classe K}

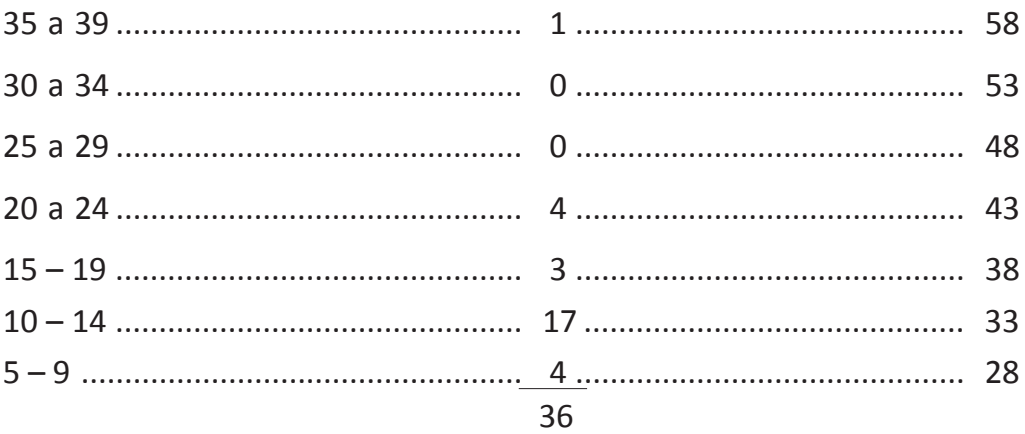

Nota - A classe K conta 6 interinos, num total de 42 empregados.

Os interinos não estão incluídos no quadro acima.

Para o cálculo, os números de ocupantes das diversas classes são

$$
N_{N}=18 N_{M}=20 N_{L}=40 N_{k}=36
$$

O período considerado para o cálculo é $\mathrm{T}=10$ anos

I) Classe $\mathrm{N}$

Dentro do período de 10 anos não haverá aposentadorias compulsórias por limite de idade (68 anos).

Por aposentadorias por tempo de serviço (35 anos) são possíveis:

$$
\begin{aligned}
& \text { no grupo de } 35 \text { a } 39 \text { anos de serviço......... } 1 \text { vaga } \\
& \text { no grupo de } 30 \text { a } 34 \text { anos de serviço.......... } 3 \text { vagas } \\
& \text { no grupo de } 25 \text { a } 29 \text { anos de serviço.......... } 4 \text { vagas } \\
& \text { total.................................................... } 8 \text { vagas }
\end{aligned}
$$

\begin{tabular}{|c|c|c|}
\hline Idade & Funcionários & Vagas a esperar \\
\hline 43 & 4 & $4 \times 0.2250=0.9000$ \\
\hline 38 & 4 & $4 \times 0.1726=0.6904$ \\
\hline 33 & 2 & $2 \times 0.1510=0.3020$ \\
\hline
\end{tabular}

Além destas, são possíveis as seguintes vagas por morte, de acordo com a tabela de mortalidade do $\S 39$ : 
O total de vagas a esperar na classe $\mathrm{N}$, dentro de dez anos, é, pois, teoricamente de

$$
V_{N}=8+1.8924=9.892 \quad 4 \text { vagas }
$$

II) O número provavel de promoções da classe $\mathrm{M}$ para $\mathrm{N}$ nos dez anos considerados é, pois, de

$$
P_{M N}=V_{N}=9.8924
$$

III) A probabilidade de acesso de um empregado qualquer da classe $\mathrm{M}$ para $\mathrm{N}$ é

$$
\omega_{M N}=\frac{P_{M N}}{N_{M}-V_{M}}
$$

$O$ número $V_{\mathrm{M}}$ de vagas na classe $\mathrm{M}$, é

Por limite de idade (68 anos).....zéro

Por tempo de serviço (35 anos):

no grupo de 30 a 34 anos de serviço.... 1 vaga

no grupo de 25 a 29 anos de serviço.... 3 vagas

$$
4 \text { vagas }
$$

Por morte

$\begin{array}{ccc}\text { Idade } & \text { Funcionários } & \text { Vagas } \\ 43 & 8 & 8 \times 0.2250=1.8000 \\ 38 & 6 & 6 \times 0.1726=1.0356 \\ 33 & 2 & 2 \times 0.1510=\frac{0.3020}{3.1376}\end{array}$

O total de vagas a esperar na classe $M$ é, pois

$$
V_{M}=4+3.1376=7.137 \quad 6 \text { vagas }
$$

A probabilidade de acesso de um empregado qualquer da classe $\mathrm{M}$ é, portanto

$$
\omega_{M N}=\frac{9.8924}{20-7.137}-76,9 \%
$$

IV) O número médio anual de promoções da classe $\mathrm{M}$ para $\mathrm{N}$ é

$$
m_{M N}=\frac{V_{N}}{T} \frac{9.8924}{10}=0.989 \text { promoções }
$$




$$
\begin{aligned}
& \theta_{K M}=5.54+9.00 \quad=14.54 \text { anos } \\
& \theta_{K N}=5.54+9.00+7.80=22.34 \text { anos } \\
& \theta_{L N}=9.00+7.80 \quad=16.80 \text { anos }
\end{aligned}
$$

que são os tempos médios necessários para passar de classe $K$ para $L$, $K$ para $M, L$ para N, etc. Temos assim o seguinte quadro:

\section{Tempo necessário para promoção}

Da classe

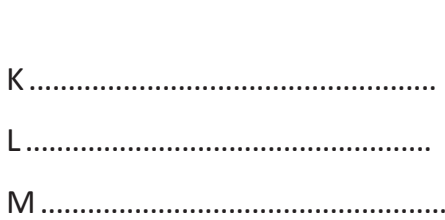

Para a classe

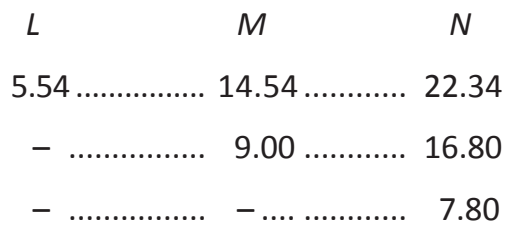

Verificando pelas tabelas de sobrevivência e mortalidade qual deva ser o número de sobreviventes da classe $\mathrm{K}$ no fim de 5.54 anos, 14.54 anos, 22.34 anos, podemos obter a percentagem de ocupantes da classe $\mathrm{K}$ que devem atingir as classes L, M, N.

Com este processo achamos que, dos 36 atuais ocupantes da classe $\mathrm{K}$,

$90 \%$ devem chegar a $\mathrm{L}$

$73 \%$ devem chegar a $M$

$57 \%$ devem chegar a $\mathrm{N}$

e analogamente achamos os seguintes resultados para os atuais ocupantes das classes L e M:

dos 40 empregados da classe L,

$82 \%$ devem chegar a $\mathrm{M}$

$68 \%$ devem chegar a $\mathrm{N}$

e dos 20 ocupantes da classe $\mathrm{M}$

$85 \%$ devem chegar a $\mathrm{N}$.

\section{$\mathrm{VI}$ - Conclusões}

I) O sistema a que está sujeito o funcionário público, e que regula a sua remuneração e as suas promoções representa um modo de solucionar o problema fundamental das relações entre o empregador - que no caso é o Govêrno - e o empregado. Esse problema básico é o da adequada remuneração de serviços, ou seja o dos salários. 
II) No salário, o que importa é o seu valor real, que representa o poder aquisitivo. Este valor real depende da produção total do País, pois a essa produção corresponde maior ou menor quantidade de mercadorias oferecidas pela mesma quantia em dinheiro. $\mathrm{O}$ salário deve, portanto, ser reajustado periodicamente de acôrdo com as flutuações do custo da vida; a remuneração dos empregados públicos deve ser controlada pela estatística de custo da vida.

III) Na operação de serviços industriais o Estado deve portar-se tanto quanto possível como um empregador particular, especialmente quanto aos empregados das carreiras profissionais.

A remuneração desses funcionários deve obedecer aos princípios que regem os salários nas indústrias: princípio da proporcionalidade da remuneração ao valor da contribuição de empregado e princípio da raridade relativa da mão de obra em face das disponibilidades do capital e das necessidades da indústria.

IV) Deve ser considerado no serviço do Govêrno o emprêgo em maior escala dos sistemas de pagamento pelo resultado do trabalho (salários por tarefa, métodos de prêmios).

V) $\mathrm{O}$ acesso do funcionário público aos cargos de melhor remuneração dentro da sua carreira, ou a sua promoção, obedece a dois critérios: o da antiguidade e o do merecimento, subordinados ambos à existência de vagas a serem preenchidas.

A verificação da antiguidade é simples; a classificação por merecimento apresenta dificuldades sérias. A determinação de efetuar promoções somente quando existem vagas é justificada pela conveniência de manter as despezas de pessoal dentro de certos limites.

VI) O critério da promoção por antiguidade indica a conveniência da redução ao mínimo do número de quadros do funcionalismo, que deverão, si possível, ser reunidos em um quadro único para o efeito de promoções segundo esse critério. A fusão dos quadros permitirá oferecer a todos os empregados acesso por antiguidade em condições semelhantes.

VII) Para as promoções por merecimento é tambem indicada a conveniência da fusão dos quadros.

O sistema atual de apreciação do merecimento dos funcionários públicos deve ser simplificado.

VIII) A atual organização do serviço público, no que se refere a pessoal, e especialmente a empregados de carreiras profissionais, poderá ser modificada de acôrdo com as normas seguintes:

- organização de carreiras nos moldes atuais, constituídas de classes sucessivas, a cada classe pertencendo todos os cargos do mesmo padrão de vencimentos; 
para cada carreira sendo determinados os limites inferior e superior do padrão de vencimentos;

- fusão de todas as classes de mesmo padrão de vencimentos em uma só, ou no menor número possível, para o efeito de promoções por antiguidade ou por merecimento;

- classificação das funções em padrões de remuneração análogos aos padrões dos cargos, em cada serviço ou repartição, de acôrdo com a importância, responsabilidade e exigências técnicas de cada função;

- remuneração do funcionário pelo padrão da função que estiver desempenhando, a não ser quando este seja inferior ao padrão do seu cargo efetivo, que então prevalecerá;

- promoção por merecimento somente de funcionários que estiverem desempenhando funções de padrão superior ao dos seus respectivos cargos.

Deve assim ser realçada a importância das funções.

IX) A possibilidade de acesso nas carreiras é tão importante quanto a remuneração atribuída a cada cargo.

A estatística aplicada permite estabelecer a proporcionalidade entre os números de logares das várias classes constituintes de uma carreira de modo a proporcionar aos funcionários que integram essas classes possibilidades de acesso de acôrdo com as responsabilidades e exigências dos serviços.

\section{Referências bibliográficas}

SALÁRIOS - Encyclopaedia Britannica.

Serviço Público Brasileero - A organização dos serviços industriais do Estado - Do autor.

Estatística - Estatística - Método e Aplicação - De Bulhões Carvalho. 
RSP 